\section{Growth potential of Listeria monocytogenes in sliced turkey bresaola packed in modified atmosphere}

\author{
Elena Dalzini, ${ }^{1}$ Elena Cosciani-Cunico, ${ }^{1}$ \\ Stefano D'Amico, ${ }^{1}$ Chiara Sfameni, \\ Barbara Bertasi, ${ }^{1}$ Marina N. Losio, ${ }^{1}$ \\ Andrea Serraino, ${ }^{2}$ Paolo Daminelli ${ }^{1}$ \\ 'Laboratorio di Microbiologia degli \\ Alimenti, Istituto Zooprofilattico \\ Sperimentale della Lombardia e \\ dell'Emilia Romagna B. Ubertini, Brescia; \\ 2Dipartimento di Scienze Mediche \\ Veterinarie, Università Bologna, Ozzano \\ dell'Emilia (BO), Italy
}

\begin{abstract}
According to EC Regulation No 2073/2005, for food business operators that produce readyto-eat (RTE) product, it is crucial to be able to demonstrate if the product supports the growth of Listeria monocytogenes. The objective of the study was therefore to evaluate the behaviour of $L$. monocytogenes in sliced RTE turkey bresaola (made by cured turkey breast $4.5 \% \mathrm{NaCl}$, $1 \%$ sodium lactate, sodium nitrite $150 \mathrm{ppm}$ and flavouring) during the shelf life of the product, simulating a contamination during the slicing operation. Considering a shelf life of 90 days, as defined by manufacturer, the packages of sliced bresaola were stored at $5^{\circ} \mathrm{C}$ for 7 days and at $8^{\circ} \mathrm{C}$ for the remaining storage time ( 83 days). L. monocytogenes count decreased during storage test from 1.43/1.98 log cfu/g in the three batches tested to $1.03 \mathrm{log} \mathrm{cfu} / \mathrm{g}$ in one batch and to undetectable levels in the other two batches. The results show that the investigated product is unable to support the growth of $L$. monocytogenes.
\end{abstract}

\section{Introduction}

Listeria monocytogenes is widely distributed in nature and the association of this pathogen with meat and slaughter environment is well established (Autio et al., 2000). L. monocytogenes may contaminate meat products through raw materials, but several studies revealed that environmental contamination is the most frequent source of $L$. monocytogenes in finished products (Barbuti and Parolari, 2002; Colak et al., 2007). In deli ready-to-eat (RTE) meats, slicing equipment was demonstrated to be a vehicle for $L$. monocytogenes contamination (Lin et al., 2006). The scientific report of EFSA (2010) reported that $L$. monocytogenes was detected in $1.5 \%$ of the 3636 units of poultry meat products tested, ranging from 0 to $7.5 \%$ positive units in broiler meat and from 0 to $11.8 \%$ in turkey meat; in RTE poultry meats the proportion of $L$. monocytogenes positive units ranged between 0.1 to $1.6 \%$. The Community legislation (Regulation No. 2073/2005/EC) lays down food safety criteria for $L$. monocytogenes in RTE: $L$. monocytogenes must not be present in levels exceeding 100 colony forming units (cfu)/g during the shelf life of a product; in addition, in RTE foods that are able to support the growth of the bacterium, $L$. monocytogenes must not be present in $25 \mathrm{~g}$ at the time of leaving the production plant unless the producer can demonstrate, to the satisfaction of the competent authority, that the product will not exceed the limit of 100 $\mathrm{cfu} / \mathrm{g}$ throughout its shelf life. Little is known about the fate of $L$. monocytogenes on different types of deli meats in particular on sliced deli meats; the objective of the study was therefore to evaluate the behaviour of $L$. monocytogenes in sliced RTE turkey bresaola made by cured turkey breast during the shelf life of the product, simulating a contamination during the slicing operation. Considering a shelf life of 90 days (as defined by manufacturer) the packages of sliced bresaola were stored at $5^{\circ} \mathrm{C}$ for 7 days to simulate optimal storage temperature at the producer plant, and at $8^{\circ} \mathrm{C}$ for the remaining storage time ( 83 days) to simulate home storage considering that more than $50 \%$ of the European household fridges hold temperature beyond $6-8^{\circ} \mathrm{C}$ (AFFSA, 2008).

\section{Materials and Methods}

\section{Bresaola samples}

Three batches of turkey bresaola (turkey breast, $4.5 \% \mathrm{NaCl}, 1 \%$ sodium lactate, sodium nitrite $150 \mathrm{ppm}$ and flavouring), sliced and packaged in a modified atmosphere $\left(30 \% \mathrm{CO}_{2}\right.$ and $70 \% \mathrm{~N}_{2}$ ), were obtained from a local manufacturer. Twenty one packs of each batch for a total of 63 packs (100 g each) of turkey bresao$l a$, were used in the study. For each batch 3 packs were used to verify the absence of natural contamination by $L$. monocytogenes; 3 packs were analysed at the beginning of the shelf life (day 0 ) and 3 packs at the end of the shelf life (90 days after storage at $5^{\circ} \mathrm{C}$ for 7 days and at $8^{\circ} \mathrm{C}$ for the remaining 83 days) for the mesophilic lactic acid bacteria (LAB) enumeration and for the measurement of $\mathrm{pH}$; and water activity $\left(\mathrm{a}_{\mathrm{w}}\right)$. The other 12 packs were used for the surface inoculation test.

\section{Bacterial cultures and inoculum preparation}

Three strains of $L$. monocytogenes, classified by $E c o$ RI ribotyping, were used in this study:
Correspondence: Elena Dalzini, Dipartimento di Microbiologia degli Alimenti, Istituto Zooprofilattico Sperimentale della Lombardia e dell'Emilia Romagna B. Ubertini, via A. Bianchi 9, 25124 Brescia, Italy.

Tel. +39.030 .2290611 - Fax: +39.030 .2290542 .

E-mail: elena.dalzini@izsler.it

Key words: Challenge test, Listeria monocytogenes, Growth potential, Turkey bresaola.

Conflict of interests: the authors declare no potential conflict of interests.

Acknowledgements: the authors are grateful to Paola Monastero and Stefania Duccoli (Laboratorio di Microbiologia degli Alimenti, IZSLER) for scientific support and technical assistance.

Funding: this study was financially supported by Italian Minister of Health within the research project Milano Expo 2015: garantire la sicurezza alimentare - valorizzare le produzioni CCM2012EXP02015.

Received for publication: 7 January 2014.

Revision received: 29 January 2014.

Accepted for publication: 30 January 2014.

This work is licensed under a Creative Commons Attribution 3.0 License (by-nc 3.0).

(C) Copyright E. Dalzini et al., 2014

Licensee PAGEPress, Italy

Italian Journal of Food Safety 2014; 3:2231

doi:10.4081/ijfs.2014.2231

ATCC $^{\circledR} 19115^{\mathrm{TM}}$ (DUP 1042) and $L$. monocytogenes field strains Lm171718 and Lm171767 (both DUP 1038) isolated from two different swine sausages. Stock cultures were kept frozen $\left(-80^{\circ} \mathrm{C}\right)$ in Brain Heart Infusion (BHI; Oxoid, Basingstoke, UK) broth supplemented with $20 \%$ glycerol until use; strains were inoculated into $\mathrm{BHI}$ and incubated at $37^{\circ} \mathrm{C}$ for $24 \mathrm{~h}$ and than inoculated in BHI broth and incubated at $8^{\circ}$ to reach the beginning of the stationary phase (Uyttendaele et al., 2004). The three strains cultures, each at the same approximate concentration ( $c a .7 \log \mathrm{cfu} \mathrm{g}^{-1}$ ) were mixed; counts of each culture were confirmed by serial decimal dilution and plating in Agar Listeria Ottaviani Agosti (ALOA; Microbiol Diagnostici, Cagliari, Italy) The multi-strain cocktail was centrifuged for $60 \mathrm{~min}$ at $4^{\circ} \mathrm{C}, 4000 \mathrm{~g}$ and the pellet re-suspended in sterile physiological solution and appropriately diluted.

\section{Surface inoculation}

For each batch, 12 packs of bresaola were used for experimental inoculation: packs were aseptically opened and the slices were inoculated on the top surface with $1 \% \mathrm{v}: \mathrm{w}$ of the multi-strain cocktail of $L$. monocytogenes to a 
final concentration of about $1.5-2 \mathrm{log} \mathrm{cfu} / \mathrm{g}$. The inoculum was distributed over the entire surface with a sterile L-shaped plastic cell spreader (Incofar, Modena, Italy) and then the slices were re-packed into sterile polyethylene bags in modified atmosphere $\left(30 \% \mathrm{CO}_{2}\right.$ and $\left.70 \% \mathrm{~N}_{2}\right)$ using S100-Tecnovac equipment [Tecnovac, Grassobbio (BG), Italy]. Inoculated packs were stored at $5^{\circ} \mathrm{C}$ for 7 days and at $8^{\circ} \mathrm{C}$ for the remaining 83 days. $L$. monocytogenes enumeration was carried out at 0,40,60 and 90 days of storage on three replicates samples for each batch.

\section{Microbiological and physico-chemi- cal analysis}

The slices were transferred into plastic onechamber filter stomacher bags (NEOMED, London, UK) and homogenised 1:3 w:v in sterile peptone water (PW) (CONDA, Madrid, Spain) for $3 \mathrm{~min}$ in a Stomacher 400 blender (Seward Medical, London, UK). Decimal dilutions in sterile PW were prepared from each bag. To verify the absence of natural contamination on control samples, at time zero the qualitative analysis for $L$. monocytogenes was performed according to ISO 11290-1 (ISO, 1996). Quantitative analysis for L. monocytogenes enumeration was performed on contaminated samples according to ISO 11290-2 (ISO, 1998). The mesophilic lactic acid bacteria (LAB) count was carried out by pour plating 1 $\mathrm{mL}$ of appropriate dilution in MRS agar (MRS; Microbiol Diagnostici) incubated at $30^{\circ} \mathrm{C}$ for $72 \mathrm{~h}$. The $\mathrm{pH}$ values were determined using a HI 223 Calibration checkTM Microprocessor pH meter (Hanna Instrument, USA) equipped with a Gel-Glass electrode (Hamilton, Switzerland). Water activity $\left(a_{w}\right)$ was measured at $25^{\circ} \mathrm{C}$ with the aw recorder AquaLab, series 3, Model TE (Decagon Devices, Inc., Pullman, WA, USA) in accordance to ISO/FDIS 21807 (ISO/FDIS, 2004).

\section{Statistical analysis}

Microbiological counting results were expressed as colony forming unit (cfu) per gram. Microbial counts were reported as log $\mathrm{cfu} / \mathrm{g}$. The average and standard deviations of microbial counts and physico-chemical values were determined from the average of three samples at each sampling time for each batch. Analysis of variance (ANOVA) was carried out to evaluate the difference of $\mathrm{pH}, a_{w}$ and microbial counts at different storage time. The significance were statistically analysed by Student $t$-test at a 95\% confidence interval $(\mathrm{P}<0.05)$ using $\mathrm{R}$ statistical software version 2.7.0 (R Development Core Team, 2008).

The growth potential $(\delta)$ of $L$. monocytogenes was calculated as difference between the median concentration at the end of shelf life (day 90) and the median concentration at the beginning of the shelf life (day 0 ), in three replicates, for three batches. The maximum growth potential $\left(\delta_{\max }\right)$ was calculated as maximal difference between day 90 and day 0 among the 3 batches (EUCRL, 2008).

\section{Results}

Examination of not inoculated samples at the beginning of shelf life revealed the absence of natural $L$. monocytogenes contamination in sliced turkey bresaola. Average of initial values ( $\mathrm{N}=3$ batch; $\mathrm{n}=3$ replicates) of $\mathrm{pH}$ and $a_{w}$ were $5.55 \pm 0.05$ (range of 5.43-5.63) and $0.923 \pm 0.010$ (range of $0.911-0.939$ ) respectively; at the end of the shelf life, average values of $\mathrm{pH}$ and $a_{w}$ were $5.45 \pm 0.11$ (range of 5.32-5.67), and $0.925 \pm 0.008$ (range of $0.912-0.939$ ) respectively. The values of $\mathrm{pH}$, mesophilic lactic acid bacteria (LAB) count at days 0 and 90 are reported in Table 1 . No significant differences $(\mathrm{P}>0.05)$ were observed between LAB $\log$ counts at the beginning and at the end of the shelf life; the physico-chemical properties showed moderate but significant changes $(\mathrm{P}<0.05)$ during the storage under the defined conditions.

Starting from values of 1.50-1.81 log cfu/g in the three batches at the day of inoculation, $L$. monocytogenes count decreased to $1.03 \pm 0.07$ $\log \mathrm{cfu} / \mathrm{g}$ in batch 1 , and below the level of detection $(<0.47 \log \mathrm{cfu} / \mathrm{g})$ in batches 2 and 3 at the end of the shelf life (90 days). The growth potential $(\delta)$ of $L$. monocytogenes ranged from $-1.32 \mathrm{log} \mathrm{cfu} / \mathrm{g}$ in batch 2 to -0.58 $\log \mathrm{cfu} / \mathrm{g}$ in batch 1 ; the maximum growth potential $\left(\delta_{\max }\right)$ of $L$. monocytogenes on sliced turkey bresaola was $-0.58 \log \mathrm{cfu} / \mathrm{g}$. The average values of $L$. monocytogenes log counts in three contaminated batches are shown in Table 1.

\section{Discussion and Conclusions}

The growth potential of $L$. monocytogenes in foods depends from many factors, the most important being the strain(s), injury or stress applied to the strain(s), intrinsic properties of the food (e.g. pH, NaCl content, $a_{w}$, food composition, associated microflora, antimicrobial constituents) and extrinsic properties (e.g. temperature profile, gas atmosphere) (EUCRL, 2008). In agreement with EC Regulation No. 2073/2005, products with $p H 4.4$ or aw 0.92, products with $\mathrm{pH}<5.0$ and $a_{w}<0.94$ and products with a shelf life of less than five days belong to the category of RTE foods that not support the growth of $L$. monocytogenes. The regulation also states that other categories of products can also belong at this category, subject to scientific justification. In the present study, the physico- chemical properties $(\mathrm{pH}$ and $\mathrm{a}_{\mathrm{w}}$ ) of the sliced turkey bresaola showed a

Table 1. Evolution of $L$. monocytogenes, lactic acid bacteria (log cfu/g) and $\mathrm{pH}$ on three batches of turkey bresaola during the shelf life (average \pm standard deviation of three samples for each contaminated batch).

\begin{tabular}{|c|c|c|c|c|}
\hline & & & & \\
\hline & 0 & 40 & 60 & 90 \\
\hline Batch 1 & & & & \\
\hline L. monocytogenes $(\log \mathrm{cfu} / \mathrm{g})$ & $1.68 \pm 0.28$ & $1.50 \pm 0.14$ & $1.34 \pm 0.12$ & $1.03 \pm 0.07$ \\
\hline LAB (log cfu/g) & $8.09 \pm 0.07$ & na & na & $7.90 \pm 0.16$ \\
\hline $\mathrm{pH}$ & $5.60 \pm 0.03$ & na & na & $5.45 \pm 0.01$ \\
\hline Batch 2 & & & & \\
\hline L. monocytogenes $(\log \mathrm{cfu} / \mathrm{g})$ & $1.81 \pm 0.17$ & nd & nd & nd \\
\hline $\mathrm{LAB}(\log \mathrm{cfu} / \mathrm{g})$ & $8.16 \pm 0.03$ & na & na & $8.29 \pm 0.19$ \\
\hline $\mathrm{pH}$ & $5.51 \pm 0.07$ & na & na & $5.35 \pm 0.04$ \\
\hline Batch 3 & & & & \\
\hline L. monocytogenes $(\log \mathrm{cfu} / \mathrm{g})$ & $1.50 \pm 0.13$ & $1.13 \pm 0.32$ & $0.99 \pm 0.07$ & nd \\
\hline LAB $(\log \mathrm{cfu} / \mathrm{g})$ & $8.05 \pm 0.15$ & na & na & $7.81 \pm 0.22$ \\
\hline $\mathrm{pH}$ & $5.55 \pm 0.04$ & na & na & $5.58 \pm 0.11$ \\
\hline
\end{tabular}

LAB, lactic acid bacteria; na, not analysed; nd, not detected. 
variability between the different batches that do not allow to clearly define the product category with regard of supporting or not $L$. monocytogenes growth. The results of the present study showed that the investigated sliced turkey bresaola do not support the growth of $L$. monocytogenes even when turkey bresaola were stored in condition of moderate thermal abuse.

The observed decrease of $\mathrm{pH}$ during the 90 days of storage (from 5.51/5.60 to 5.35/5.58) in the three batches may have influenced the survival of $L$. monocytogenes but cannot explain alone the decrease in $L$. monocytogenes count given that the growth/no growth interfaces of Listeria reported by Le Marc et al. (2002) are 5.50 and $4.6-4.7$ respectively at 5 and $10^{\circ} \mathrm{C}$; similarly the minimal $\mathrm{a}_{\mathrm{w}}$ levels for growth and survival of $L$. monocytogenes were reported to be $0.90-0.92$ with lower survival rates in $\mathrm{NaCl}$ adjusted media.

The results underscore that $L$. monocytogenes count reduction could be explained by the sum of different factors, such as values of $\mathrm{pH}$ (Buchanan et al., 1993) and $a_{w}$ (Sabatakou et al., 2001), the addition of nitrite (Kouakou et al., 2009) and packaging in modified atmosphere (MAP) (Sørheim et al., 2004); also, even the indigenous microbiota of RTE meat products could affect the behavior of $L$. monocytogenes (Lecompte et al., 2008; Ross et al., 2009; Mellefont and Ross, 2007) by competition for carbohydrates, acids and bacteriocins production (Serraino et al., 2013). In particular Glass et al. (2008) reportd that a minimum $30 \mathrm{ppm}$ nitrite will enhance the antilisterial activity of lactate in RTE poultry meat and that $150 \mathrm{ppm}$ of sodium nitrite doubles the lag-phase of $L$. monocytogenes. The combination of $2 \%$ sodium lactate and $0.5 \%$ of acetate prevent pathogen growth in sliced pork saveloy with a little as $60 \mathrm{ppm}$ of sodium nitrite (Junker et al. 2000). The presented data are currently needed, given the lack of similar information in the literature, and may be a useful scientific tool for food manufacturers that produce RTE meat products with similar characteristics, to demonstrate whether their product supports the growth of $L$. monocytogenes or not, in accordance with EC Regulation No. 2073/2005 (European Commission, 2005).

\section{References}

AFSSA, 2008. Technical guidance document on shelf-life studies for Listeria monocytogenes in ready-to-eat foods. Agence Francaise de Securite Sanitaire des Aliments ed., Maisons-Alfort, France. Available from: http://www.fsai.ie/ uploadedFiles/EU_Guidance_shelflife_lis- teria_monocytogenes_en.pdf

Autio T, Säteri T, Fredriksson-Ahomaa M, Rahkio M, Lundén J, Korkeala H, 2000. Listeria monocytogenes contamination pattern in pig slaughterhouses. J Food Prot 63:1438-42.

Barbuti S, Parolari G, 2002. Validation of manufacturing process to control pathogenic bacteria in typical dry fermented product. Meat Sci 62:323-9.

Buchanan RL, Golden MH, Whiting RC, 1993. Differentiation of the effects of $\mathrm{pH}$ and lactic or acetic concentration on the kinetics of Listeria monocytogenes inactivation. J Food Prot 56:474-8.

Colak H, Hampikyan H, Ulusoy B, Bingol EB, 2007. Presence of Listeria monocytogenes in Turkish style fermented sausage (sucuk). Food Control 18:30-2.

EFSA, 2010. The community summary report on trends and sources of zoonoses and zoonotic agents and food-borne outbreaks in the European Union in 2008. EFSA Journal 8:1496.

EUCRL, 2008. Technical guidance document on shelf-life studies for Listeria monocytogenes in ready-to-eat foods. European Union Community Reference Laboratory for Listeria monocytogenes, French Food Safety Agency ed., Maisons-Alfort, France.

European Commission, 2005. Regulation of the European Parliament and of the Council of 15 November 2005 on microbiological criteria for foodstuffs, 2073/2005/CE. In: Official Journal, L 388/1, $22 / 12 / 2005$.

Glass K, McDonnell L, Sawyer C, Claus J, 2008. Minimum nitrite levels required to control Listeria monocytogenes on ready-to-eat poultry products manufactured with lactate and diacetate. University of Wisconsin-Madison ed., WI, USA. Available from: http://www.meatami.com/ht/a/Get DocumentAction/i/42348

ISO, 1996. Microbiology of food and animal feeding stuffs. Horizontal method for the detection and enumeration of Listeria monocytogenes. Part 1: Detection method. ISO 11290-1 1996/Amd. 1:2004 (E). International Standardization Organi zation ed., Geneva, Switzerland.

ISO, 1998. Microbiology of food and animal feeding stuffs -Horizontal method for the detection and enumeration of Listeria monocytogenes. Part 2: Enumeration method - Amendment 1: Modification of the enumeration method. ISO 11290-2 (1998/Amd. 1:2005). International Stan dardization Organization ed., Geneva, Switzerland.

ISO/FDIS, 2004. Microbiology of food and animal feeding stuffs-determination of water activity. ISO/FDIS 21807:2004. Internatio- nal Organization for Standardization, Geneve, Switzerland.

Juncher D, Vestergaard C S, Soltoft Jensen J, Weber C J, Bertelsen G, Skibsted LH, 2000. Effects of chemical hurdles on microbiological and oxidative stability of a cooked cured emulsion type meat product. Meat Sci 55:483-91.

Kouakou P, Ghalfi H, Destain J, DuboisDauphin R, Evrard P, Thonart P, 2009. Effects of curing sodium nitrite additive and natural meat fat on growth control of Listeria monocytogenes by the bacteriocin-producing Lactobacillus curvatus strain CWBI-B28. Food Microbiol 26:623-8.

Lecompte JY, Kondjoyan A, Sarter S, Portanguen S, Collignan A, 2008. Effects of steam and lactic acid treatments on inactivation of Listeria innocua surface inoculated on chicken skins. Int $\mathrm{J}$ Food Microbiol 127:155-61.

Le Marc Y, Huchet V, Bourgeois CM, Guyonnet JP, Mafart P, Thuault D, 2002. Modelling the growth kinetics of Listeria as a function of temperature, $\mathrm{pH}$ and organic acid concentration. Int J Food Microbiol 73:21937.

Lin C, Takeuchi K, Zhang L, Dohm CB, Meyer JD, Hall PA, Doyle MP, 2006. Cross contamination between processing equipment and deli meats by Listeria monocytogenes. J Food Prot 69:71-9.

Mellefont LA, Ross T, 2007. Effect of potassium lactate and a potassium lactate-sodium diacetate blend on Listeria monocytogenes growth in modified atmosphere packaged sliced ham. J Food Prot 70:2297-305.

Ross T, Rasmussen S, Fazil A, Paoli G, Sumner J, 2009. Quantitative risk assessment of Listeria monocytogenes in ready-to-eat meats in Australia. Int $\mathrm{J}$ Food Microbiol 131:128-37.

Sabatakou 0, Watsos E, Mantis F, Ramantanis S, 2001. Classification of Greek meat products on the basis of $\mathrm{pH}$ and aw values. Fleischwirtschaft Int 2:92-6.

Serraino A, Finazzi G, Marchetti G, Daminelli P, Riu R, Giacometti F, Losio MN, Rosmini $R, 2013$. Fate of Listeria monocytogenes during production and storage of artisan water buffalo mozzarella cheese. It J Food Sci 25:16-22.

Sørheim 0, Ofstad R, Lea P, 2004. Effect of carbon dioxide on yield, texture and microstructure of cooked ground beef. Meat Sci 67:231-6.

Uyttendaele M, Rajkovic A, Benos G, Francois K, Devlieghere F, Debevere J, 2004. Evaluation of a challenge testing protocol to assess the stability of ready-to-eat cooked meat products against growth of Listeria monocytogenes. Int $\mathrm{J}$ Food Microbiol 90:219-36. 